\title{
EVALUASI PENILAIAN 5S DI AREA PENYIMPANAN ALAT PADA BEBERAPA PROYEK KONSTRUKSI
}

\section{S Assessment Evaluation in the Tools Storage Area at some Construction Projects}

\author{
Ferdiana Soekresno ${ }^{1}$, Andi $^{2}$, Jani Rahardjo ${ }^{3}$ \\ ${ }^{1}$ Mahasiswa Program Studi Magister Teknik Sipil Universitas Kristen Petra \\ Alamat korespondesi : Jl. Siwalankerto No. 121-131 Telp. (031) 8439040 \\ Email :m01514013@john.petra.ac.id \\ ${ }^{2}$ Dosen Program Studi Teknik Sipil Universitas Kristen Petra \\ Alamat korespondesi : Jl. Siwalankerto No. 121-131 Telp. (031) 8439040 \\ Email : andi@peter.petra.ac.id \\ ${ }^{3}$ Dosen Program Studi Teknik Industri Universitas Kristen Petra \\ Alamat korespondesi : Jl. Siwalankerto No. 121-131 Telp. (031) 8439040 \\ Email : jani@peter.petra.ac.id
}

\begin{abstract}
$5 S$ is a concept that emphasizes on working attitude in the management of the physical conditions of the workplace. $5 S$ is an abbreviation of Seiri, Seiton, Seiso, Seiketsu, and Shitsuke. Work in an organized condition can be beneficial, so that workers do not get tired easily, give rise to concern for jobs, high participation, and good work completion. Implementation of $5 S$ concept in the storage area of construction project is very important for sorting, structuring, cleaning, and maintenance, which affects the efficiency and effectiveness of work. The goal of this paper is to assess and evaluate the concept of $5 S$ in the storage area of construction project, to determine whether the extent of the $5 S$ concept has been applied. This research was conducted with case study on five construction projects in Surabaya and Mojokerto. It was found on the result, that $5 S$ concept has never been fully applied in construction project. Seiso get a pretty good score, considering cleanliness must be maintained in the project area. Whereas, for seiri, seiton and shitsuke get bad scores, because 4 of 5 existing projects still keep the broken tools, do not have lay out for their storage area, and the lack of awareness of the discipline. Seiketsu scores very badly because the activity is considered a continuation of the previous $3 S$. $5 S$ concept has not been applied in construction projects because of the unfamiliar concept of $5 S$, difficulty performing guidance and training to workers before the project begins, the project deadline which makes contractors more focused on the progress of the completion of the project, as well as there is only a few number and type of tools.
\end{abstract}

Keywords : Assessment, 5s, Storage Area, Construction Project

\begin{abstract}
Abstrak
5S merupakan konsep penerapan sikap kerja yang menekankan pada pengelolaan kondisi fisik tempat kerja. $5 S$ merupakan singkatan dari Seiri, Seiton, Seiso, Seiketsu, dan Shitsuke. Bekerja pada tempat yang terorganisir, membuat pekerja tidak cepat lelah, menimbulkan kepedulian terhadap pekerjaan, partisipasi yang tinggi, dan penyelesaian kerja yang baik. Penerapan konsep $5 S$ pada area penyimpanan sangat penting karena berpengaruh terhadap efisiensi dan efektifitas pekerjaan. Tujuan penelitian ini adalah melakukan penilaian dan evaluasi konsep $5 \mathrm{~S}$ di area penyimpanan proyek, untuk mengetahui sejauh mana konsep $5 S$ telah diterapkan. Penelitian ini dilakukan dengan studi kasus pada 5 proyek konstruksi di Surabaya dan Mojokerto. Hasil penelitian menunjukkan bahwa konsep $5 S$ belum diterapkan sepenuhnya pada proyek konstruksi. Seiso mendapatkan nilai yang cukup baik, mengingat kebersihan wajib dijaga di area proyek. Sedangkan, faktor seiri, seiton, dan shitsuke mendapatkan nilai yang buruk, karena 4 dari 5 proyek yang ada masih menyimpan alat rusak, tidak ada tata letak untuk area penyimpan alat, dan kurangnya kesadaran akan kedisiplinan. Seiketsu mendapatkan nilai yang sangat buruk karena aktivitas yang dinilai merupakan lanjutan dari $3 S$ sebelumnya. Konsep $5 S$ belum diterapkan di proyek konstruksi karena belum dikenalnya konsep $5 S$, kesulitan melakukan pengarahan dan pelatihan pada pekerja, adanya deadline proyek, serta jumlah dan jenis alat yang sedikit.
\end{abstract}

Kata kunci : Penilaian, 5s, Area Penyimpanan, Proyek Konstruksi 


\section{PENDAHULUAN}

$5 S$ merupakan suatu konsep penerapan sikap kerja yang menekankan pada pengelolaan kondisi fisik tempat kerja yang terorganisir. Nama $5 S$ sendiri berasal dari huruf pertama istilah Jepang, yaitu Seiri, Seiton, Seiso, Seiketsu, dan Shitsuke yang menjadi semboyannya. Bekerja pada tempat yang terorganisir dengan baik, aman, dan sehat dapat bermanfaat agar pekerja tidak cepat kelelahan, sehingga semangat kerja dapat dipertahankan dalam waktu yang relatif lama. Selain itu juga akan menimbulkan rasa kepedulian terhadap pekerjaan, partisipasi yang tinggi, dan penyelesaian kerja yang baik (Apriyatna, 2008).

Dalam bukunya, "The Five Keys to a Total Quality Environment", Osada (1995) mengemukakan bahwa $5 S$ merupakan serangkaian aktivitas pemilahan, penataan, pembersihan, pemeliharaan dan pembiasaan, yang diperlukan untuk melaksanakan pekerjaan dengan baik. Dengan adanya konsep $5 S$, seorang yang bekerja di dalam proyek konstruksi tidak akan merasa berbeda dengan orang yang bekerja di dalam kantor, karena mereka juga dapat bekerja dalam kondisi fisik yang nyaman dan efektif (Apriyatna, 2008).

Konsep $5 S$ terdiri dari kata seiri yang berarti ringkas, seiton yang berarti rapi, seiso yang berarti resik, seiketsu yang berarti rawat dan shitsuke yang berarti rajin. Ringkas berhubungan dengan prinsip 'just in time' I tepat waktu, yang artinya hanya apa yang dibutuhkan, hanya jumlah yang dibutuhkan, dan hanya ketika dibutuhkan (Hirano, 1996). Seiton adalah menyimpan barang pada lokasi yang seharusnya atau lokasi yang telah ditentukan sehingga mudah untuk digunakan dan memberikan label sehingga dapat mengurangi pemborosan waktu dalam mencari, mengambil, dan mengembalikan barang.

Seiso berarti memeriksa agar kondisi lingkungan maupun peralatan selalu bersih, baik sebelum maupun sesudah penggunaan, terutama pada saat meninggalkan area pekerjaan. Seiketsu berarti memastikan semua kondisi peralatan, mesin, lingungan, dan kondisi lainnya sesuai dengan aturan yang telah disepakati dan menjaga agar tetap terpelihara. Shitsuke berarti menjadikan seluruh prosedur kerja $5 S$ sebagai kebiasaan yang dilaksanakan secara ideal dan produktif dari waktu ke waktu, dengan diikuti komitmen untuk melaksanakannya.

Pada penelitian ini dilakukan pada area penyimpan alat yang meliputi alat kerja, alat keselematan kerja, dan alat kebersihan. Alat kerja yang dimaksudkan adalah alat kerja yang merupakan milik kontraktor utama, tidak termasuk alat - alat kerja milik tukang.

Area penyimpanan merupakan komponen penting dari operasi logistik dan berkontribusi dalam kecepatan pekerjaan dan biaya dalam supply chains. Oleh karena itu, penerapan konsep $5 S$ pada area penyimpanan di proyek konstruksi sangat penting karena pemilahan, penataan, pembersihan, dan pemeliharaan alat mempengaruhi efisiensi dan efektifitas pekerjaan yang dilakukan.

Pada penelitian sebelumnya, implementasi konsep $5 S$ dapat meningkatkan safety di proyek (Leino et al., 2014) dan juga diaplikasikan di negara Palestina (Enshassi \& Zaiter, 2014). Namun penelitian mengenai konsep $5 S$ belum pernah dilaksanakan di proyek - proyek konstruksi di Indonesia. Pada penelitian ini dilakukan penilaian konsep $5 S$ pada beberapa proyek konstruksi di Surabaya dan Mojokerto yang difokuskan di area penyimpanan. Penelitian ini dimulai dari melakukan pengumpulan data kondisi proyek pada saat ini sampai dengan penilaian dan evaluasi proyek berdasarkan konsep $5 S$. Dengan adanya penelitian ini, diharapkan dapat meningkatkan efisiensi, efektivitas dan kualitas pengerjaan, serta juga menciptakan area penyimpanan yang nyaman, teratur, dan rapi.

\section{METODE PENELITIAN}

Langkah pertama yang dilakukan adalah studi literatur, dimana di dalamnya didapatkan pembelajaran mengenai teori dasar dan konsep - konsep 5S. Selain itu, mempelajari pedoman dalam melakukan penilaian $5 S$, mengetahui berbagai macam jenis alat konstruksi yang biasanya digunakan dalam proyek konstruksi, dan pengertian dari area penyimpanan.

Pengumpulan data dilakukan dengan kunjungan secara langsung untuk mengobservasi dan interview petugas penanggung jawab area penyimpanan pada beberapa proyek konstruksi di Surabaya dan Mojokerto. Terdapat dua jenis data yang dikumpulkan pada penelitian ini. Data yang pertama adalah data mengenai daftar 
inventaris alat - alat konstruksi yang berada di area penyimpanan. Alat konstruksi di proyek terdiri dari alat kerja, alat keselamatan, dan alat kebersihan. Data ini bersifat data sekunder yang dijadikan dasar dalam melakukan penilaian dengan form $5 S$. Sedangkan data primer yang perlu dikumpulkan adalah penilaian dengan menggunakan form $5 S$ berdasarkan kondisi aktual di area penyimpanan.

Form $5 S$ / pedoman penilaian $5 S$ adalah acuan yang digunakan untuk mengukur sejauh mana konsep $5 S$ sudah diterapkan pada proyek konstruksi. Pedoman ini berisi penilaian tentang variabel aktivitas dan kriteria evaluasi berdasarkan konsep $5 S$ yang diadopsi dari pedoman penilaian penerapan $5 R$ di perusahaan dan instansi pemerintah propinsi Jawa Timur (Pemerintah Propinsi Jawa Timur, 2005). Hal ini dikarenakan belum terdapat pedoman penilaian konsep $5 S$ pada proyek konstruksi. Form $5 S$ tersebut dapat dilihat pada Tabel 1.

Tabel 1. Form Pedoman Penilaian 5S

\begin{tabular}{|c|c|c|}
\hline Faktor & Kode & Kriteria \\
\hline \multirow{5}{*}{ Seiri } & S1.1 & Area penyimpanan sudah tidak menyimpan alat yang tidak dibutuhkan. \\
\hline & S1.2 & $\begin{array}{l}\text { Sudah ada prosedur / tata cara membuang alat yang tidak diperlukan (bernilai dan } \\
\text { tidak bernilai). }\end{array}$ \\
\hline & S1.3 & $\begin{array}{l}\text { Alat yang dibutuhkan berada di dekat area kerja dan jumlah serta item / jenisnya } \\
\text { sesuai kebutuhan. }\end{array}$ \\
\hline & S1.4 & Tidak ada peralatan kerja rusak dibiarkan begitu saja di area penyimpanan. \\
\hline & $\mathrm{S} 1.5$ & $\begin{array}{l}\text { Lokasi penyimpanan (termasuk alat ukur / pemeriksaan) sudah ditentukan serta mudah } \\
\text { dan cepat untuk mendapatkan dan mengembalikannya. }\end{array}$ \\
\hline \multirow{5}{*}{ Seiton } & $\mathrm{S} 2.1$ & Alat telah disimpan di tempatnya sesuai klasifikasi. \\
\hline & $\mathrm{S} 2.2$ & $\begin{array}{l}\text { Layout / tata letak tempat penyimpanan telah ditentukan dan telah diberi batas yang } \\
\text { jelas. }\end{array}$ \\
\hline & $\mathrm{S} 2.3$ & Semua alat telah ada label / identitas. \\
\hline & S2.4 & $\begin{array}{l}\text { Penyimpanan dokumen (file, standar kerja, daily control, form, dll) sudah ditentukan } \\
\text { dan memudahkan setiap orang untuk mendapatkannya. }\end{array}$ \\
\hline & $\mathrm{S} 2.5$ & Semua personil menaati aturan penyimpanan dan lay out yang telah ditetapkan. \\
\hline \multirow{5}{*}{ Seiso } & S3.1 & $\begin{array}{l}\text { Sarana / alat kebersihan sudah tersedia sesuai jenis dan jumlahnya serta } \\
\text { penempatannya sudah sesuai ketentuan. }\end{array}$ \\
\hline & $\mathrm{S} 3.2$ & Pembersihan area kerja sudah dilakukan secara rutin dan terjadwal sesuai ketentuan. \\
\hline & S3.3 & $\begin{array}{l}\text { Area tanggung jawab 5R resik sudah ditentukan dan pelaksanaannya telah sesuai } \\
\text { ketentuan. }\end{array}$ \\
\hline & S3.4 & Alat K3 dibersihkan dan diperiksa secara teratur dan tidak kadaluarsa. \\
\hline & S3.5 & Tidak ada tempelan, tulisan dan coretan yang tidak relevan dengan area kerja. \\
\hline \multirow{5}{*}{ Seiketsu } & S4.1 & Standarisasi Ringkas, Rapi, Resik, Rawat, Rajin sudah diterapkan. \\
\hline & S4.2 & $\begin{array}{l}\text { Eliminasi sumber kotor dan penyederhanaan proses, prosedur sudah dibahas, } \\
\text { dilaksanakan dan dimonitor / dievaluasi. }\end{array}$ \\
\hline & S4.3 & Penerapan visual kontrol, anti salah telah dilaksanakan di semua area. \\
\hline & S4.4 & $\begin{array}{l}\text { Pemeriksaan berkala dan evaluasi / audit penerapan } 5 \mathrm{R} / 5 \mathrm{~S} \text { telah dilaksanakan secara } \\
\text { periodik. }\end{array}$ \\
\hline & S4.5 & $\begin{array}{l}\text { Sistem sumbang saran / Kaizen telah diterapkan di semua area dan semua personil } \\
\text { telah melaksanakannya. }\end{array}$ \\
\hline \multirow{2}{*}{ Shitsuke } & S5.1 & $\begin{array}{l}\text { Sikap kerja semua personil sudah menunjukkan kebiasaan positif (atribut kerja, tepat } \\
\text { waktu, disiplin, dll). }\end{array}$ \\
\hline & S5.2 & $\begin{array}{l}\text { Semua personil secara aktif dan kreatif memberikan saran - saran perbaikan baik } \\
\text { kelompok maupun perorangan. }\end{array}$ \\
\hline
\end{tabular}


Lanjutan Tabel 1. Form Pedoman Penilaian $5 S$

\begin{tabular}{ccl}
\hline Faktor & Kode & \multicolumn{1}{c}{ Kriteria } \\
\hline Shitsuke & S5.4 & $\begin{array}{l}\text { Target / sasaran / quality objective perusahaan, departemen, bagian, kelompok, } \\
\text { perorangan telah disosialisasikan dan pencapaiannya telah direkam, dimonitor, } \\
\text { dievaluasi, ditindaklanjuti dan disosialisasikan. }\end{array}$ \\
& S5.5 & $\begin{array}{l}\text { Sudah ada activity board yang menyajikan informasi area masing-masing (hasil } \\
\text { Kaizen, efisiensi, produktivitas, hasil audit, dll). } \\
\text { Kegiatan / penerapan 5R/5S sudah dimasukkan / dikaitkan dengan ISO / GKM / PA / } \\
\text { job description. }\end{array}$ \\
\hline
\end{tabular}

Pada melakukan penilaian menggunakan form 5S, nilai yang diperoleh berupa huruf $\mathrm{A}$ sampai dengan E. Dengan dasar penilaian, nilai A merupakan nilai yang sangat baik sedangkan nilai $\mathrm{E}$ merupakan nilai yang sangat buruk. Nantinya nilai - nilai tersebut akan dikonversikan dalam bentuk poin untuk mempermudah pada saat pengolahan data. Tabel konversi dari nilai huruf menjadi angka dapat dilihat pada Tabel 2.

Tabel 2. Tabel Konversi Nilai ke Poin

\begin{tabular}{ccc}
\hline \multicolumn{2}{c}{ Nilai } & \multirow{2}{*}{ Keterangan } \\
Poin & Huruf & \\
\hline $4.1-5$ & A & Sangat Baik \\
$3.1-4$ & B & Baik \\
$2.1-3$ & C & Cukup \\
$1.1-2$ & D & Buruk \\
$0-1$ & E & Sangat Buruk \\
\hline
\end{tabular}

Setelah didapatkan nilai untuk masing masing proyek, akan dilakukan rata - rata dari masing - masing konsep. Kemudian langkah yang terakhir, dari semua nilai yang ada, pada setiap proyek dihitung rata - rata total, sehingga diperoleh nilai akhir penerapan konsep $5 S$ pada sebuah proyek. Nilai akhir yang diperoleh pada masing - masing proyek mengenai penerapan konsep $5 S$ bertujuan untuk mengukur sejauh mana penerapan konsep $5 S$ sudah dilakukan pada setiap proyek konstruksi.

\section{HASIL DAN PEMBAHASAN}

Pengumpulan data dilakukan dengan kunjungan secara langsung untuk mengobservasi area penyimpanan pada beberapa proyek konstruksi di Surabaya dan Mojokerto. Tabel rekapitulasi penilaian berisi kolom Kode, N 1, N 2 dan Rata-rata. Kolom Kode merupakan penomoran yang mewakili urutan setiap pertanyaan dari pedoman penilaian penerapan $5 S$. Kolom $\mathrm{N} \quad 1$ merupakan hasil penilaian pada saat kunjungan pertama ke proyek, yaitu pada awal minggu. Kolom N 2 merupakan hasil penilaian pada kunjungan kedua ke proyek, yaitu pada akhir minggu. Pada saat menilai menggunakan form $5 S$, nilai yang didapatkan berupa huruf A sampai E. Dari setiap nilai yang didapatkan, dilakukan rata- rata untuk mendapatkan rata - rata masing penilaian $5 S$, rata - rata dari masing - masing proyek, dan rata - rata secara keseluruhan.

Tabel 3. Tabel Rekapitulasi Penilaian Konsep 5S

\begin{tabular}{|c|c|c|c|c|c|c|c|c|c|c|c|c|c|c|c|}
\hline \multirow[t]{2}{*}{ Kode } & \multicolumn{14}{|c|}{ Nilai } & Apartemen E \\
\hline & N1 & $\mathrm{N} 2$ & Rata2 & N1 & $\mathrm{N} 2$ & Rata2 & N1 & $\mathrm{N} 2$ & Rata2 & N1 & $\mathrm{N} 2$ & Rata2 & N1 & $\mathrm{N} 2$ & Rata2 \\
\hline S1.1 & 4 & 4 & 4 & 4 & 4 & 4 & 5 & 5 & 5 & 4 & 4 & 4 & 4 & 4 & 4 \\
\hline $\mathrm{S} 1.2$ & 1 & 1 & 1 & 1 & 1 & 1 & 5 & 5 & 5 & 1 & 1 & 1 & 1 & 1 & 1 \\
\hline $\mathrm{S} 1.3$ & 2 & 2 & 2 & 3 & 3 & 3 & 4 & 4 & 4 & 3 & 3 & 3 & 2 & 2 & 2 \\
\hline S1.4 & 2 & 2 & 2 & 2 & 2 & 2 & 5 & 5 & 5 & 2 & 2 & 2 & 2 & 2 & 2 \\
\hline S1.5 & 2 & 2 & 2 & 1 & 1 & 1 & 5 & 5 & 5 & 1 & 1 & 1 & 1 & 1 & 1 \\
\hline \multicolumn{3}{|c|}{ Rata - rata Seiri } & 2.2 & & & 2.2 & & & 4.8 & & & 2.2 & & & 2 \\
\hline $\mathrm{S} 2.1$ & 1 & 1 & 1 & 2 & 2 & 2 & 5 & 2 & 3.5 & 1 & 3 & 2 & 1 & 1 & 1 \\
\hline $\mathrm{S} 2.2$ & 1 & 1 & 1 & 1 & 1 & 1 & 5 & 5 & 5 & 1 & 1 & 1 & 1 & 1 & 1 \\
\hline $\mathrm{S} 2.3$ & 1 & 1 & 1 & 1 & 1 & 1 & 5 & 5 & 5 & 1 & 1 & 1 & 1 & 1 & 1 \\
\hline $\mathrm{S} 2.4$ & 1 & 1 & 1 & 1 & 1 & 1 & 5 & 5 & 5 & 1 & 1 & 1 & 1 & 1 & 1 \\
\hline $\mathrm{S} 2.5$ & 1 & 1 & 1 & 1 & 1 & 1 & 5 & 5 & 5 & 1 & 1 & 1 & 1 & 1 & 1 \\
\hline \multicolumn{3}{|c|}{ Rata - rata Seiton } & 1 & & & 1.2 & & & 4.7 & & & 1.2 & & & 1 \\
\hline
\end{tabular}


Lanjutan Tabel 3. Tabel Rekapitulasi Penilaian Konsep $5 S$

\begin{tabular}{|c|c|c|c|c|c|c|c|c|c|c|c|c|c|c|c|}
\hline \multirow[t]{2}{*}{ Kode } & \multicolumn{3}{|c|}{ Mall A } & \multicolumn{3}{|c|}{ Hotel B } & \multicolumn{3}{|c|}{ Nilai } & \multicolumn{3}{|c|}{ Hotel D } & \multicolumn{3}{|c|}{ Apartemen E } \\
\hline & N1 & N2 & Rata2 & N1 & N2 & Rata2 & N1 & $\mathrm{N} 2$ & Rata2 & $\mathrm{N} 1$ & $\mathrm{~N} 2$ & Rata2 & N1 & $\mathrm{N} 2$ & Rata2 \\
\hline S3.1 & 3 & 3 & 3 & 3 & 3 & 3 & 3 & 3 & 3 & 2 & 2 & 2 & 3 & 3 & 3 \\
\hline S 3.2 & 1 & 1 & 1 & 4 & 4 & 4 & 4 & 4 & 4 & 4 & 4 & 4 & 4 & 4 & 4 \\
\hline S 3.3 & 1 & 1 & 1 & 5 & 5 & 5 & 5 & 5 & 5 & 1 & 1 & 1 & 5 & 5 & 5 \\
\hline S3.4 & 1 & 1 & 1 & 1 & 1 & 1 & 1 & 1 & 1 & 1 & 1 & 1 & 1 & 1 & 1 \\
\hline S3.5 & 3 & 3 & 3 & 5 & 5 & 5 & 5 & 5 & 5 & 5 & 5 & 5 & 5 & 5 & 5 \\
\hline \multicolumn{3}{|c|}{ Rata - rata Seiso } & 1.8 & & & 3.6 & & & 3.6 & & & 2.6 & & & 3.6 \\
\hline S4.1 & 1 & 1 & 1 & 1 & 1 & 1 & 1 & 1 & 1 & 1 & 1 & 1 & 1 & 1 & 1 \\
\hline S4.2 & 1 & 1 & 1 & 1 & 1 & 1 & 1 & 1 & 1 & 1 & 1 & 1 & 1 & 1 & 1 \\
\hline S4.3 & 1 & 1 & 1 & 1 & 1 & 1 & 1 & 1 & 1 & 1 & 1 & 1 & 1 & 1 & 1 \\
\hline S4.4 & 1 & 1 & 1 & 1 & 1 & 1 & 1 & 1 & 1 & 1 & 1 & 1 & 1 & 1 & 1 \\
\hline S4.5 & 1 & 1 & 1 & 1 & 1 & 1 & 1 & 1 & 1 & 1 & 1 & 1 & 1 & 1 & 1 \\
\hline \multicolumn{3}{|c|}{$\begin{array}{c}\text { Rata - rata } \\
\text { Seiketsu }\end{array}$} & 1 & & & 1 & & & 1 & & & 1 & & & 1 \\
\hline S5.1 & 3 & 3 & 3 & 3 & 3 & 3 & 4 & 4 & 4 & 3 & 3 & 3 & 3 & 3 & 3 \\
\hline S5.2 & 1 & 1 & 1 & 1 & 1 & 1 & 1 & 1 & 1 & 1 & 1 & 1 & 1 & 1 & 1 \\
\hline S5.3 & 4 & 4 & 4 & 4 & 4 & 4 & 5 & 5 & 5 & 4 & 4 & 4 & 4 & 4 & 4 \\
\hline S5.4 & 1 & 1 & 1 & 1 & 1 & 1 & 1 & 1 & 1 & 1 & 1 & 1 & 1 & 1 & 1 \\
\hline S5.5 & 1 & 1 & 1 & 1 & 1 & 1 & 1 & 1 & 1 & 1 & 1 & 1 & 1 & 1 & 1 \\
\hline \multicolumn{3}{|c|}{$\begin{array}{l}\text { Rata - rata } \\
\text { Shitsuke }\end{array}$} & 2 & & & 2 & & & 2.4 & & & 2 & & & 2 \\
\hline
\end{tabular}

\section{Penerapan Konsep 5S pada Proyek Mall A}

Pada proyek Mall A, hasil penilaian seiri menunjukan bahwa masih ada alat rusak di area penyimpanan alat kerja dan belum ditentukan tindakan selanjutnya untuk alat tersebut (S1.4). Kemudian dari hasil seiton menunjukan tidak adanya lay out penyimpanan, label / identitas untuk setiap alat kerja, dan lokasi penyimpanan dokumen yang berhubungan dengan area penyimpanan alat kerja. (S2.2-S2.4) Sedangkan hasil seiso menunjukkan minimnya jumlah alat K3 dan alat kebersihan, serta tidak adanya jadwal pembersihan alat maupun area kerja proyek (S3.1-S3.2). Sistem yang digunakan mulai dari proses pendataan alat, peminjaman, sampai pengembalian masih sangat sederhana, yaitu dengan pencatatatan jumlah alat di area penyimpanan, kondisi alat, dan siapa yang memakai alat tersebut.

Hasil penilaian seiketsu menunjukkan bahwa proyek ini belum pernah menerapkan konsep $5 S$ sebelumnya (S4.1-S4.5). Hal ini didasarkan pada nilai yang diperoleh mendapatkan hasil yang sangat buruk untuk masing - masing kriteria yang ada. Sedangkan hasil penilaian shitsuke menunjukkan bahwa sikap kerja pekerja sudah menunjukkan kedisiplinan, meskipun membutuhkan reward dan punishment dalam pencapaiannya (S5.1), serta sudah ada target yang ingin dicapai pada proyek ini (S5.3). Namun, untuk pemberian saran, keberadaan activity board yang berkaitan dengan $5 S$, dan kegiatan yang berkaitan dengan $5 S$ masih belum ada (S5.4-S5.5).

Dapat dilihat bahwa pada proyek Mall A, hasil penilaian dari seiri, seiton, seiso, seiketsu, dan shitsuke menunjukkan bahwa di proyek ini belum pernah mengenal apalagi menerapkan konsep 5S. Hal ini diperkuat dengan pernyataan dari penanggung jawab area penyimpanan alat kerja yang tidak mengetahui sama sekali mengenai konsep $5 S$.

Menurut penanggung jawab area penyimpanan alat kerja, konsep $5 S$ belum perlu diterapkan pada proyek Mall A. Hal ini dikarenakan jumlah alat yang ada tidak sebanding dengan persiapan untuk menerapkan konsep $5 S$, ditambah lagi dengan kendala tidak ada tenaga yang akan mengajarkan konsep $5 S$ serta kurangnya kualitas SDM pekerja yang akan menerima. Dengan sistem yang sudah dijalankan, belum pernah terjadi kendala yang menyebabkan kerugian yang besar, baik dari segi waktu 
maupun biaya. Oleh karena itu, menurutnya masih belum perlu diterapkan konsep $5 S$ pada proyek Mall A.

\section{Penerapan Konsep 5S pada Proyek Hotel B}

Pada proyek Hotel B, hasil penilaian seiri menunjukan bahwa masih ada alat rusak di area penyimpanan alat kerja dan belum ditentukan tindakan selanjutnya untuk alat tersebut (S1.4). Kemudian, dari hasil seiton menunjukan tidak adanya lay out penyimpanan, label / identitas untuk setiap alat kerja, dan lokasi penyimpanan dokumen yang berhubungan dengan area penyimpanan alat kerja (S2.2-S2.4). Dokumen tersebut hanya diletakkan seadanya di dalam area penyimpanan alat K3 dan alat kebersihan, baik pada saat kunjungan pertama maupun kunjungan kedua. Sedangkan hasil seiso menunjukkan minimnya jumlah alat $\mathrm{K} 3$ dan alat kebersihan (S3.1). Tidak ada pembersihan maupun pemeriksaan terhadap alat K3 pada proyek ini(S3.4). Namun sudah ditentukan jadwal pembersihan area kerja proyek, walaupun secara lisan (S3.2). Sistem yang digunakan masih sederhana dengan pencatatan daftar alat yang masuk ke proyek, pengecekan setiap mau memasuki hari libur dan hari pertama kerja setelah libur, serta pencatatan siapa saja yang meminjam alat setiap awal shift kerja.

Hasil penilaian seiketsu menunjukkan bahwa konsep $5 S$ belum pernah diterapkan di proyek ini (S4.1-S4.5), oleh karena itu diperoleh hasil yang mendukung dengan nilai penerapan seiketsu yang jelek. Hal ini dikarenakan tidak ada perawatan $3 S$ pertama di proyek tersebut. Sedangkan hasil shitsuke menunjukkan bahwa pekerja yang ada sudah menunjukkan kedisiplinan dan ada pencatatan target yang ada pada proyek (S5.1-S5.2). Meskipun dalam pengerjaannya tidak melibatkan pekerja, tidak ada activity board yang menunjukkan pelaksanaan konsep 5S, dan tidak ada kegiatan - kegiatan yang berhubungan dengan konsep $5 S$ (S5.3S5.5).

Dapat dilihat bahwa pada proyek Hotel B ini, hasil penilaian dari seiri, seiton, seiso, seiketsu, dan shitsuke menunjukkan bahwa di proyek ini belum pernah mengenal dan menerapkan konsep 5S. Hal ini diperkuat juga dengan pernyataan dari penanggung jawab area penyimpanan alat kerja yang tidak mengetahui konsep $5 S$.

Menurut penanggung jawab area penyimpanan, konsep $5 S$ sepertinya lebih cocok diterapkan pada proyek dengan nilai investasi alat yang besar agar tidak sampai terjadi kerugian, baik karena alat yang rusak maupun hilang. Sedangkan untuk proyek Hotel B, konsep $5 S$ belum perlu diterapkan apalagi sampai jika diterapkan secara detail.

Kendala yang mungkin akan dihadapi dalam penerapan konsep $5 S$ adalah kurangnya pengetahuan para pekerja sehingga sulit menerapkan konsep $5 S$. Selain itu, jumlah alat pada proyek ini tidak terlalu banyak, sehingga sistem yang ada, mulai dari pengecekan dan peminjaman alat dinilai sudah cukup baik dan mudah dimengerti oleh setiap pekerja proyek. Berdasarkan alasan alasan ini dapat disimpulkan bahwa pada proyek Hotel B belum perlu menerapkan konsep $5 S$.

\section{Penerapan Konsep 5S pada Proyek Apartemen C}

Pada proyek Apartemen C, hasil penilaian seiri menunjukan bahwa sudah tidak ada alat rusak di area penyimpanan alat kerja (S1.4), dan jika ada alat yang rusak prosedurnya pun sudah jelas, yaitu dengan cara dikembalikan ke tempat workshop untuk ditukar dengan alat yang baru atau diperbaiki. Kemudian, dari hasil seiton menunjukan sudah ada lay out penyimpanan dan label / identitas untuk setiap alat kerja yang dilengkapi dengan nomor registrasi, serta lokasi penyimpanan dokumen yang berhubungan dengan area penyimpanan alat kerja(S2.2-S2.4). Sedangkan hasil seiso menunjukkan jumlah alat K3 yang sudah sesuai dengan jenisnya hanya saja jumlahnya yang agak berlebihan (S3.1). Area tanggung jawab pembersihan pun sudah diatur setiap minggunya oleh atasan yang bertanggung jawab (S3.3). Hanya saja belum ada kegiatan untuk pembersihan dan pemeriksaan terhadap alat K3 (S3.4). Tulisan dan coretan yang tidak relevan juga tidak ada pada proyek ini (S3.5). Sistem yang digunakan pada proyek ini dimulai dari pendataan alat sampai sistem 
peminjaman alat sudah sangat jelas dan teratur. Sistem peminjaman alat kerja misalnya, dibagi dalam beberapa shift peminjaman dan peminjaman harus disertai dengan bon alat dari kantor area penyimpanan yang bersangkutan.

Hasil penilaian seiketsu menunjukkan bahwa konsep $5 S$ belum ditbudayakan pada proyek ini sehingga diperoleh hasil yang sangat buruk (S4.1-S4.5). Pada proyek ini, baik standarisasi $5 S$; penerapan visual kontrol; pemeriksaan berkala dan evaluasi / audit penerapan $5 S$; maupun sistem sumbang saran / Kaizen belum diterapkan. Sedangkan hasil shitsuke menunjukkan bahwa proyek telah sedikit menerapkannya, dengan sikap kerja pekerja yang disiplin, tepat waktu, dan menggunakan atribut kerja secara lengkap (S5.1). Namun, masih belum ada keterlibatan pekerja dalam memberikan saran (S5.2), belum ada activity board yang menyajikan informasi mengenai penerapan konsep $5 S$ dan tidak ada kegiatan penerapan $5 S$ (S5.4S5.5).

Dapat dilihat bahwa pada proyek Apartemen C ini, hasil penilaian dari seiri, seiton, seiso, seiketsu, dan shitsuke menunjukkan bahwa di proyek ini sudah menerapkan konsep $5 S$ walaupun masih belum sempurna. Namun, dari hasil interview setiap penanggung jawab area penyimpanan masih tidak mengetahui konsep $5 S$.

Berdasarkan hasil interview dengan tiap penanggung jawab area penyimpanan proyek Apartemen $\mathrm{C}$, diperoleh bahwa sebenarnya konsep $5 S$ perlu diterapkan jika alat yang ada di proyek berjumlah banyak dan beraneka ragam. Dengan menerapkan konsep $5 S$, tentunya akan mempermudah dan membantu dalam mengawasi setiap alat maupun material yang ada di proyek. Selain itu, mempermudah para pekerja apabila membutuhkan alat atau material tertentu. Persiapan yang dibutuhkan memang sedikit rumit, namun sebanding dengan hasil yang diperoleh, jika proyek memiliki banyak sekali jenis dan jumlah alat maupun material. Oleh karena itu, menurut penanggung jawab area penyimpanan penerapan konsep $5 S$ memang dibutuhkan khususnya pada proyek Apartemen C.

\section{Penerapan Konsep 5S pada Proyek Hotel D}

Pada proyek Hotel D, hasil penilaian seiri menunjukan bahwa masih ada alat rusak di area penyimpanan alat kerja dan belum ditentukan tindakan selanjutnya untuk alat alat tersebut (S1.4). Kemudian dari hasil seiton menunjukan tidak adanya tata letak / lay out penyimpanan, label / identitas untuk setiap alat kerja, dan dokumen yang berhubungan dengan area penyimpanan alat kerja (S2.2-S2.4). Sedangkan hasil seiso menunjukkan tidak adanya pembersihan maupun pemeriksaan terhadap alat K3 pada proyek ini (S3.3), namun untuk jadwal pembersihan area kerja proyek sudah ditentukan setiap minggunya walaupun secara lisan (S3.2). Sistem penyimpanan yang ada masih sangat sederhana. Area penyimpanan alat kerja pada proyek ini terus berpindah sesuai dengan area kerja yang sedang dikerjakan oleh pekerja. Hanya pada saat permulaan proyek dan saat melakukan pemindahan area penyimpanan alat kerja, dilakukan pengecekan daftar inventaris alat kerja dengan mencatat nama dan jumlah alat.

Hasil penilaian seiketsu menunjukkan bahwa konsep $5 S$ belum diterapkan dalam proyek ini, sehingga hasil yang diperoleh sangat buruk (S4.1-S4.5). Hal ini dikarenakan seiketsu berkaitan dengan perawatan $3 S$ sebelumnya, yaitu seiri, seiton, dan seiso. Sedangkan untuk hasil penilaian shitsuke menunjukkan bahwa pekerja sudah menjalankan kedisiplinan, tepat waktu, dan menggunakan atribut, meskipun belum terlibat dalam pemberian saran yang berkaitan dengan pekerjaan proyek (S5.1S5.2). Selain itu, pada proyek ini target yang ingin dicapai sudah dicatat dan dimonitor. Namun, belum ada activity board yang menyajikan informasi mengenai penerapan konsep 5S dan tidak ada kegiatan penerapan 5S yang sudah dikaitkan dengan ISO / GKM / PA / job description pada proyek (S5.3S5.5).

Dapat dilihat bahwa pada proyek Hotel $\mathrm{D}$, hasil penilaian dari seiri, seiton, seiso, seiketsu, dan shitsuke menunjukkan bahwa di proyek ini belum pernah mengenal dan menerapkan konsep $5 S$. Hal ini diperkuat juga dengan pernyataan dari penanggung 
jawab area penyimpanan yang tidak mengetahui tentang konsep $5 S$.

Menurut penanggung jawab area penyimpanan alat kerja, konsep $5 S$ belum perlu diterapkan khususnya pada proyek Hotel D, hal ini dikarenakan jumlah alat yang ada sangat sedikit ditambah lagi area penyimpanan yang berpindah - pindah membuat kesulitan untuk menerapkan konsep $5 S$. Selain itu, bukanlah hal yang mudah untuk melatih para pekerja proyek dengan konsep baru dan merubah kebiasaan lamanya. Oleh karena alasan - alasan tersebut, konsep $5 S$ masih belum perlu diterapkan pada proyek Hotel D.

\section{Penerapan Konsep 5S pada Proyek Apartemen E}

Pada proyek Apartemen E, hasil penilaian seiri menunjukan bahwa cukup banyak alat rusak di area penyimpanan alat kerja outdoor dan belum ditentukan tindakan selanjutnya untuk alat tersebut (S1.4). Kemudian dari hasil seiton menunjukan tidak adanya lay out penyimpanan, label identitas untuk setiap alat kerja, termasuk lokasi penyimpanan dokumen yang berhubungan dengan area penyimpanan alat kerja (S2.2S2.4). Sedangkan hasil seiso menunjukkan minimnya jumlah alat K3 dan alat kebersihan (S3.1). Tidak ada pembersihan maupun pemeriksaan terhadap alat $\mathrm{K} 3$ pada proyek ini (S3.3), namun untuk jadwal pembersihan area kerja sudah ditentukan secara lisan tiap minggunya (S3.2). Sistem yang digunakan pada area penyimpanan alat kerja cukup sederhana. Dimulai dari mendaftar alat - alat yang tersedia pada saat permulaan proyek dengan mencatat jumlah dan jenis alat di area penyimpanan. Kemudian untuk proses penyimpanan alat, peminjaman alat, dan pengembalian alat dilakukan dengan pencatatatan jumlah dan jenis alat yang dipinjam dan siapa yang menggunakan alat tersebut.

Hasil penilaian seiketsu menunjukkan bahwa pada proyek ini baik standarisasi 5S; eliminasi sumber kotor dan penyederhaanaan proses / prosedur; penerapan visual kontrol dan anti salah; pemeriksaan berkala dan evaluasi / audit penerapan 5S; maupun sistem sumbang saran / Kaizen belum diterapkan
(S4.1-S4.5). Hal ini mengakibatkan buruknya penilaian seiketsu. Sedangkan hasil penilaian shitsuke menunjukkan kedisiplinan pekerja, dimana pekerja datang tepat waktu dan menggunakan atribut kerja sebelum memasuki area kerja konstruksi (S5.1). Selain itu, tujuan yang ingin dicapai sudah dicatat dan pekerjaan yang ada sudah dimonitor (S5.3). Namun, para pekerja tidak dilibatkan dalam pemberian saran - saran yang berhubungan dengan pekerjaan konstruksi (S5.2). Selain itu, belum ada activity board yang menyajikan informasi mengenai penerapan konsep 5S dan tidak ada kegiatan penerapan $5 \mathrm{~S}$ yang sudah dikaitkan dengan ISO / GKM / PA / job description pada proyek (S5.4-S5.5).

Dapat dilihat bahwa pada proyek Apartemen E, hasil penilaian dari seiri, seiton, seiso, seiketsu, dan shitsuke menunjukkan bahwa di proyek ini belum pernah mengenal dan menerapkan konsep $5 S$. Hal ini diperkuat juga dengan pernyataan dari penanggung jawab area penyimpanan yang tidak mengetahui tentang konsep $5 S$.

Menurut penanggung jawab area penyimpanan, konsep $5 S$ masih belum perlu diterapkan pada proyek Apartemen E. Hal ini dikarenakan, berdasarkan pengalaman dari penanggung jawab area penyimpanan, sistem yang ada memang kurang sempurna tetapi cukup untuk kapasitas proyek seperti proyek Apartemen E ini. Padahal jumlah alat kerja dan barang - barang lainnya cukup banyak, mulai dari alat kerja yang siap pakai sampai alat kerja yang rusak. Hanya saja, karena konsep $5 S$ termasuk hal baru, maka dibutuhkan persiapan yang matang untuk memulai penerapan konsep $5 S$ baik dari sisi manajemen maupun para pekerja, yang tentunya menyita biaya dan waktu yang cukup banyak. Oleh karena itu, dengan mempertimbangkan kelebihan dan kekurangan dari penerapan konsep $5 S$, seharusnya konsep $5 S$ perlu diterapkan pada proyek Apartemen E. 
Hasil Penilaian Penerapan Konsep 5S pada 5 Proyek Konstruksi

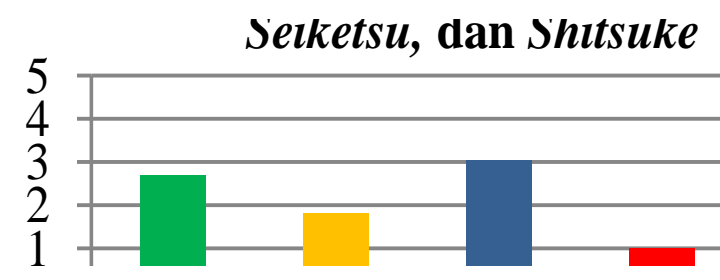

Gambar 1. Grafik Perbandingan Penilaian Seiri, Seiton, Seiso, Seiketsu, dan Shitsuke pada 5 Proyek Konstruksi

Penerapan konsep $5 S$ pada proyek konstruksi seharusnya diperlukan agar dapat meningkatkan efisiensi, efektivitas dan kualitas pengerjaan, serta menciptakan area penyimpanan yang nyaman, teratur, dan rapi. Namun, dari hasil interview, menurut 4 dari 5 penanggung jawab area penyimpanan proyek, menyatakan bahwa konsep $5 S$ belum perlu diterapkan pada proyek konstruksi. Oleh karena itu dilakukan perbandingan penilaian dari 5 konsep tersebut untuk melihat sejauh mana konsep $5 S$ secara tidak langsung diterapkan di proyek konstruksi, yang dapat dilihat pada Gambar 1 .

Dari Gambar 1, dapat dilihat bahwa seiso merupakan salah satu faktor yang sudah diterapkan di proyek konstruksi. Penerapan seiso di proyek konstruksi merupakan keharusan, karena kebersihan wajib dijaga di area proyek. Meskipun pada kenyataannya, salah satu poin seiso, yaitu menjaga kebersihan alat - alat K3 belum terlaksana dengan baik (S3.4), kecuali di proyek Mall A.

Seiton merupakan faktor yang sangat jarang / bahkan tidak diterapkan di proyek proyek konstruksi. Hal ini ditunjukkan dengan 4 dari 5 proyek konstruksi masih belum menentukan lay out / tata letak penyimpanan alat pada area penyimpanan (S2.2). Selain itu, tidak ada label / identitas pada setiap alat kerja yang digunakan di proyek (S2.1). Seiton sangat sulit untuk diterapkan di proyek, karena tidak adanya budaya rapi dalam diri pekerja proyek konstruksi.

Sedangkan, untuk hasil penilaian seiri menunjukkan bahwa 4 dari 5 proyek konstruksi masih menyimpan alat rusak di area penyimpanannya (S1.4). Dari hasil tersebut dapat ditarik kesimpulan sementara bahwa rata - rata proyek konstruksi masih mempunyai kebiasaan membiarkan alat yang rusak menumpuk di area penyimpanan.

Hasil penilaian shitsuke menunjukkan bahwa 4 dari 5 proyek konstruksi, para pekerja menjalankan kedisiplinan berdasarkan reward dan punishment yang diberikan (S5.1). Selain itu, target yang ada sudah dicatat namun belum ada tindakan pencegahan untuk mengeliminasi hal - hal yang tidak diinginkan yang dapat mempengaruhi pencapaian target (S5.2).

Hasil penilaian seiketsu merupakan yang paling buruk jika dibandingkan dengan faktor yang lainnya. Hal ini dikarenakan belum dibudayakannya konsep $5 S$ pada proyek proyek tersebut, sedangkan penilaian seiketsu berkaitan dengan aktivitas yang dilakukan setelah menjalankan $3 S$ awal, yaitu seiri, seiton, dan seiso (S4.1-S4.5).

\section{Kendala Pelaksanaan Konsep $5 S$ pada 5 Proyek Konstruksi}

Setelah melakukan penilaian dan interview pada 5 proyek konstruksi di Surabaya dan Mojokerto, diperoleh beberapa kendala yang dapat mengakibatkan konsep $5 S$ tidak diterapkan pada proyek konstruksi. Kendala - kendala tersebut antara lain:

- Belum mengenal konsep 5S

Berdasarkan hasil interview, penyebab utama tidak diterapkannya konsep $5 S$ pada proyek konstruksi adalah belum pernah mengenal konsep 5S. Namun dari hasil penilaian dan observasi yang dilakukan pada 5 proyek konstruksi tersebut, pada salah satu proyek telah menerapkan konsep $5 S$ meskipun tidak secara keseluruhan di area penyimpanan proyek.

- Sumber Daya Manusia (SDM) yang kurang memadai

Sumber Daya Manusia (SDM) merupakan salah satu faktor penting yang menunjang terlaksananya konsep $5 S$ secara keseluruhan. Berdasarkan hasil interview, penanggung jawab proyek mengatakan bahwa para pekerja dikhawatirkan belum mampu untuk menerapkan konsep 5S. Berdasarkan 
konsep $5 S$, sebelum pelaksanaan proyek, dilakukan training kepada para staff mengenai konsep $5 S$, yang nantinya akan diajarkan kepada para pekerja / tukang. Namun, kenyataannya sangat sulit untuk melaksanakan pelatihan tersebut, karena sifat proyek yang hanya sementara, sehingga pekerja juga bersifat sementara saja. Selain itu, bukanlah hal mudah untuk mengajarkan sesuatu yang baru dan merubah kebiasaan para pekerja, jika tidak dilakukan pada saat proyek dimulai. Hal lain yang dikhawatirkan adalah kegagalan penerapan konsep $5 S$ meskipun telah dilakukan pengarahan dan pelatihan. Hal ini diperkuat dengan pernyataan salah satu penanggung jawab area penyimpanan alat K3 yang mengatakan bahwa masih banyak pelanggaran yang dilakukan oleh para pekerja berkaitan dengan keselamatan kerja. Padahal telah dilakukan pelatihan dan ada peraturan yang jelas dan terperinci berkaitan dengan K3 di proyek.

- Adanya deadline proyek (waktu)

Konsep $5 S$ merupakan konsep yang baru dalam dunia konstruksi. Oleh karena itu dalam penerapannya dibutuhkan waktu untuk pengenalan dan pelatihan pada awal proyek, agar konsep ini dapat diterapkan secara keseluruhan dengan baik. Menurut penanggung jawab area penyimpanan, pengenalan dan pelatihan ini dinilai cukup menyita waktu jika dibandingkan dengan hasil yang akan diperoleh. Selain itu, adanya deadline proyek yang mengikat kontraktor, membuatnya harus lebih fokus dengan progress proyek. Sehingga penerapan konsep $5 S$ hanya akan mempersulit dirinya.

- Biaya

Menurut beberapa penanggung jawab area penyimpanan, jumlah dan jenis alat yang digunakan di proyek konstruksi tidak terlalu banyak. Hal ini menimbulkan kekhawatiran bahwa dengan menerapkan konsep $5 S$ pada area penyimpanan proyek, hasil yang didapatkan tidak sebanding dengan usaha dan biaya yang dikeluarkan / bahkan dapat menyebabkan kerugian bagi proyek tersebut.

\section{KESIMPULAN DAN SARAN}

Berdasarkan hasil penilaian yang dilakukan pada 5 proyek konstruksi, ternyata masih belum ada proyek yang menerapkan konsep $5 S$ secara menyeluruh, bahkan belum ada yang mengenal konsep tersebut.

Dari hasil penilaian didapatkan bahwa aturan yang ada pada tiap proyek, mengenai barang / alat yang ada di proyek kurang lebih sama. Dari 5 proyek, 4 diantaranya masih menyimpan alat rusak di dalam area penyimpanan dan tidak pernah menentukan tata letak / lay out penyimpanan alat. Hal ini dapat dilihat dari hasil penilaian seiri dan seiton yang buruk. Sedangkan untuk kebersihan area kerja proyek, hampir semua proyek menjaga kebersihan, kecuali proyek yang berada di Mall A. Hal ini dikarenakan kebersihan wajib dijaga di area proyek, sehingga hasil penilaian seiso menunjukkan nilai yang cukup baik. Hasil penilaian seiketsu dapat dilihat bahwa pada 5 proyek konstruksi belum pernah menerapkan konsep $5 S$, sehingga ketika dilakukan penilaian dari akivitas - aktivitas yang harus dilakukan setelah menjalankan $3 S$ pertama mendapatkan hasil yang sangat buruk. Sedangkan hasil penilaian shitsuke, menunjukkan 4 dari 5 proyek belum menentukan tindakan pencegahan tidak tercapainya tujuan yang ada dan pekerja mentaati kedisiplinan, ketepatan waktu, dan atribut kerja karena diberikan reward dan punishment.

Berdasarkan hasil interview dengan para penanggung jawab area penyimpanan, mereka merasa bahwa konsep $5 S$ belum perlu diterapkan karena terganjal beberapa kendala. Kendala - kendala tersebut antara lain, pemahaman yang kurang mengenai konsep $5 S$, SDM yang dikhawatirkan kurang memadai dan kesulitan dalam mengubah kebiasaan pekerja, deadline proyek yang dikhawatirkan tidak tercapai apabila harus melakukan pengenalan dan pelatihan konsep $5 S$ pada awal proyek, serta jumlah dan jenis alat konstruksi yang tidak terlalu banyak. 


\section{DAFTAR PUSTAKA}

Apriyatna, Y, 2007, Analisis Penerapan 5R (Ringkas, Rapi, Resik, Rawat, Rajin) di Bagian Divisi Sipil Umum II (DSU II) PT. Wijaya Karya (Persero) Tbk. pada Proyek PLTU Indramayu. (TA No. 010/BAN-PT/AK-X/S1/V/2007), Tugas Akhir Tidak Diterbitkan, Universitas Widyatama, Bandung.

Enshassi, A \& Zaiter, M. A, 2014, Implementation of Lean Tools on Safety in Construction Projects in Palestine, Paper Presented at the 22nd Annual Conference of the International Group for Lean Construction, Oslo, Norway.

Hirano, H. (1996). 5S for operators : 5 Pillars of the visual workplace. Productivity Press, Portland, OR.

Leino et al., 2014, Improving Safety Performance Through 5S Program, Paper Presented at the 22nd Annual Conference of the International Group for Lean Construction, Oslo, Norway.

Osada, Takashi. 1995. The 5S's : Five Keys to a Total Quality Environment. Jakarta : P.T Pustaka Binaman Pressindo.

Pemeritah Propinsi Jawa Timur. 2005. Pedoman penilaian penerapan $5 R$ di perusahaan dan instansi pemerintah propinsi Jawa Timur. Jawa Timur : Pemerintah Propinsi Jawa Timur 